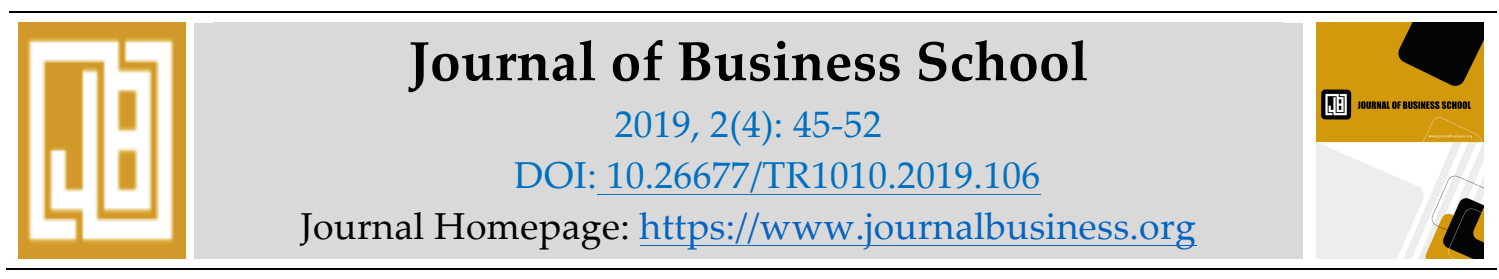

\title{
Currency Fluctuations, Inflation And Stock Market Prices: Evidence From Nigeria
}

\author{
Cordelia Onyinyechi Omodero \\ Department of Accounting, College of Management Sciences, Michael Okpara \\ University of Agriculture Umudike, Umuahia, Abia State, Nigeria. \\ cordeliaomodero@yahoo.com
}

\begin{abstract}
The role of currency fluctuations and inflation rate volatility in determining stock market prices cannot be overrated by all standards. This study examines the effect of the fluctuations in these selected macroeconomic factors on the stock market prices in Nigeria from 1999 to 2018 using data obtained from the Nigerian Stock Exchange, World Bank and CBN statistical bulletin. The regression result reveals that real exchange rate fluctuation has a significant positive influence on Nigerian stock market prices while the inflation rate volatility exerts no significant impact on stock market prices. The study recommends that the market players and the relevant authorities should put in place policies that will enable investors to hedge against the effect of the fluctuations in the macroeconomic factors which are inevitable and could be adverse on the market if precautionary measures are not taken on time.
\end{abstract}

Keywords: Exchange rate volatility, inflation rate, stock market prices, Nigerian Stock Exchange, Currency fluctuations.

\section{Introduction}

The Nigerian Stock Exchange (NSE) came into existence in 1960 and was then referred to as Lagos Stock Exchange. Following some innovations in the country, the name was eventually changed from the Lagos Stock Exchange to the present Nigerian Stock Exchange in 1977 (NSE, 2018). The Nigerian Stock Exchange is presently a member of the World Federation of Exchanges (WFE), a pioneer member of the African Stock Exchanges Association (ASEA) and a viewer at meetings of International Organization of Securities Commissions (IOSCO). In October 31, 2013, Nigerian Stock Exchange joined the United Nations Sustainable Stock Exchange (SSE) initiative (SSE, 2019). It was a collaboration that was aimed at promoting sustainability among listed companies and also an effort to create sustainable value for investors.

Presently, the Nigerian Stock Exchange (NSE) is the third largest Stock Exchange in Africa. There are 29 stock exchanges in Africa which represent 38 nations' capital markets, 21 out of the 29 are members of the African Securities Exchanges Association (ASEA). Out of the 21 members 
of ASEA, Johannesburg Stock Exchange South Africa founded in 1887 is the largest and has about 388 listed companies. The second largest is the Egyptian Exchange which was established in 1883 and currently has about 265 listed firms, the NSE comes third and it is followed by Stock Exchange of Mauritius found in 1988 with about 170 listed companies. The NSE all-share index was formulated in January 1984 with a base value of 100 . It is only the ordinary shares that are used for the computation of the index which is daily and valueweighted. The NSE share price index is a total market index, reflecting a total picture of the behaviors of the common shares quoted on the Nigerian Stock Exchange. It is calculated on a daily basis to reflect the movement in stock prices in the capital market (NSE, 2018).

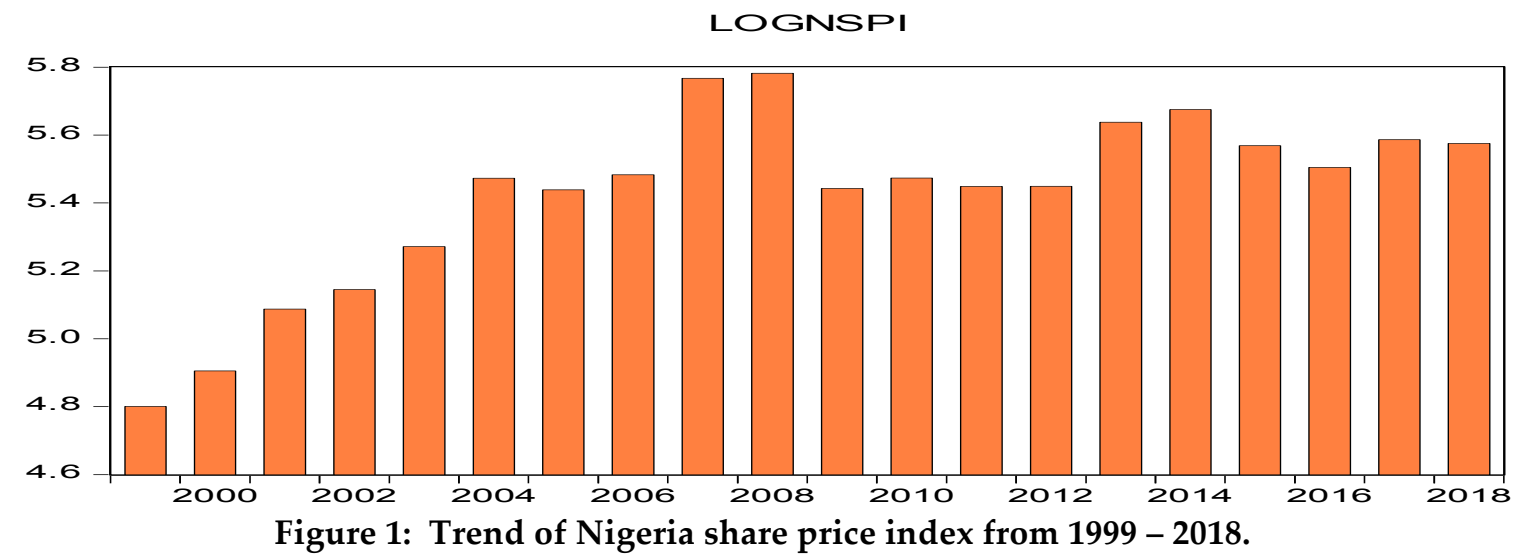

Source of Data: CBN statistical bulletin and NSE website.

The performance of stock market in Nigeria is determined by some macro-economic factors which are common economic phenomenon globally. These determinants include: the Gross Domestic Product (GDP), inflation, interest rates, exchange rates and government regulations among others. Gross domestic product (GDP) gives a comprehensive score card about the overall health of an economy. Thus, investors are very much concerned about a nations GDP report in every investment decision. Positive economic growth of a country is usually shown in the size of the GDP which helps to boost corporate profits as well as stock market performance (Mburu, 2015). This implies that a dwindling economic growth leads to a negative effect on stock market performance.

An increase in the interest rates does not have a positive influence on stock market returns. More especially, as the Banks keep increasing their rates, thereby raising the finance cost of the quoted firms and reducing their profits. The implication is that, while the investors consider the reduction in profits of the quoted companies, it leads to less demand on the stocks, thus the stock market performance is negatively affected.

Similarly, inflation affects some stocks positively while some others are negatively affected. During inflation, investors make wise investment decisions which tend to boost or demean stock market performance. The effects of inflation on an economy can be both negative and positive depending on the situation. However, inflation generally increases prices of goods and services which may be favorable or adverse to stock market returns of a country. 
LOGINFR

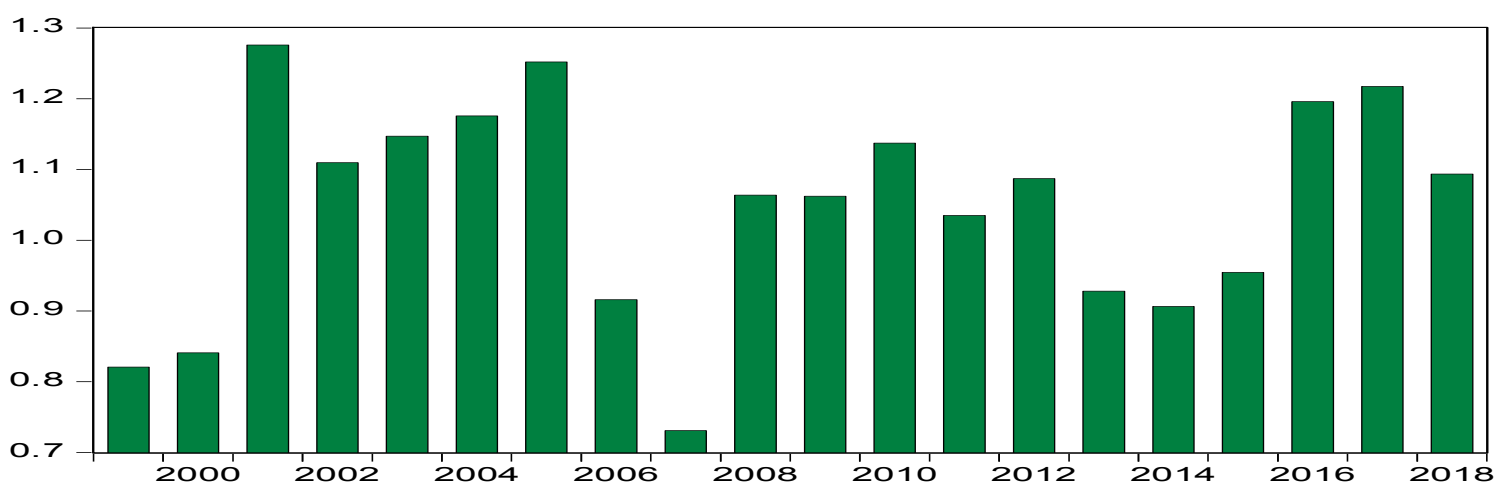

Figure 2: Trend of inflation in Nigeria from $1999-2018$.

Source of Data: World Bank

In Nigeria, the inflation rate was at its peak in 2001 followed by 2005 and 2017.

On the other hand, exchange rate is the value of one currency for the purpose of conversion to another. Exchange rate movements greatly affect the stock market returns due to its information content to the investors. Currency volatility affects stock returns and when it appreciates, especially if it is an export-oriented country, it makes the exports less attractive thereby harming the domestic stock market. Under this scenario, the quoted companies doing the export in the country become less profitable and less attractive to investors, thus the stock market loses (Muthike \& Sakwa, 2012). The frequency of exchange rate fluctuation has a major impact on the financial market (Mechri, Hamad, Peretti \& Charfi, 2019). Though the reverse is the case in a situation where the country's currency depreciates.

LOGREXG

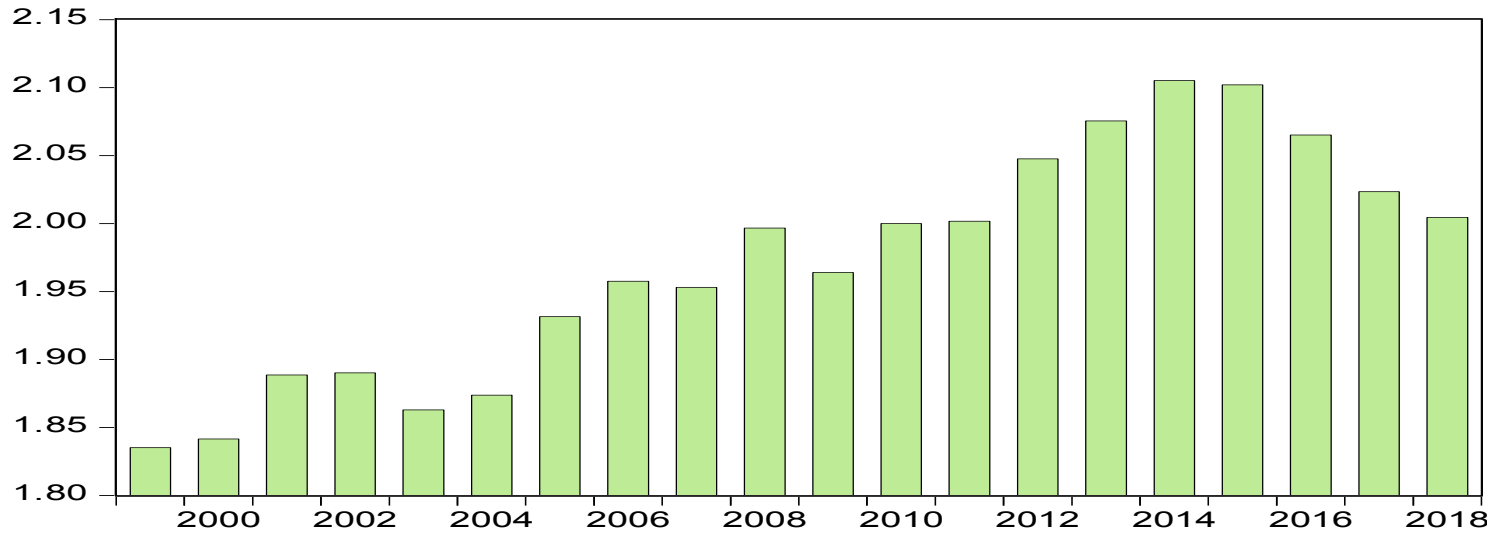

Figure 3: Trend of exchange rate in Nigeria from $1999-2018$.

\section{Source of Data: World Bank}

The exchange rate was too high in 2014 and 2015, which adversely affected the stock prices. Though from 1999 to 2004 the rise in exchange rate did not give much cause for worry, but the situation became unbearable from 2005 when the fluctuation continued without stopping.

Government regulation is another factor that affects stock market prices. For instance the introduction of certain taxes such as capital gain tax on share prices by the government affects investors who may likely look for other countries with less tax burdens on investors to do their invest their capital. Therefore, government regulations that are not favorable to investors affect 
stock market performance. These determinants affect stock market prices, but for the purpose of this study, the inflation and exchange rates volatility are considered more hurting to stock market prices in the Nigerian investment environment and have been utilized as the predictor variables.

\section{Literature review}

\subsection{Theoretical review}

The theories supporting this study are the purchasing power parity theory and the flow oriented model.

\subsubsection{Purchasing power parity (PPP) theory}

Madura (2000) advocated purchasing power parity theory which holds that currency fluctuation is a product of different inflation rates among countries. When a country's inflation rate increases, the demand for its currency declines as well as its exports due to their high prices. Consequently, the consumers and firms in that country increase their imports. Under this situation, stock prices of the listed companies involved in export in that country are affected because investors will shift attention to countries where there is relatively price stability which helps to have value for their money. PPP theory states that goods and services should have the same cost everywhere after conversion to a common currency. That means, the ratio of price level and exchange rate between two countries must be equal. PPP follows the "law of price" which maintains that a competitive markets will equalize the price of an identical product in two different countries which is expressed in a common currency. PPP is a theoretical exchange rate that allows you to buy the same amount of goods and services in every country, but the existence of inflation in a particular country, leads to decline in stock market prices in that country.

\subsubsection{Flow oriented model}

The model upholds that an underlying association between the exchange rate and stock prices. In other words, exchange rate fluctuations influences the stock prices (Mlambo, Maredza \& Sibanda, 2013). The variations in the exchange rate impacts on the attractiveness of firms by affecting both their input and output prices (Joseph, 2002). For instance, when the exchange rate rises, exporters are adversely affected because the currency appreciation will cause their goods and services to be more expensive in the international market, thereby leading to serious decline in their export. It will also reduce their competitive strength globally. As a result, their profits will reduce and investors who want to gain more returns from their investment will lose interest in those firms. This interaction establishes negative relationship between domestic currency and stock prices.

\subsection{Empirical review}

Muhammad and Rasheed (2011) assessed the relationship between stock prices and exchange rates in four South Asian Countries which comprise: Bangladesh, India, Pakistan and Sri-Lanka from 1994 to 2000. The study used Vector Error Correction model, co-integration and granger causality tests to establish a long and short run relationship between the variables. The findings indicated a long run relationship between stock prices and exchange rate for Pakistan and India while a bi-directional causality was found for Bangladesh and Sri-Lanka. Sekmen (2011) employed Auto-regressive moving average (ARMA) models to investigate the effects of exchange rate volatility on stock returns in the US from 1980 to 2008. The findings revealed that exchange rate volatility negatively affect US Stock returns. Mlambo et al. (2013) studied the effects of exchange rate volatility on the stock market in South Africa from 2002 to 2010 using 
GARCH model. The study found a weak relationship between exchange rate changes and stock market prices.

Mburu (2015) used descriptive research design and data covering a period from 2011 to 2015 to examine the relationship between exchange rate volatility and stock market performance in Kenya. The study found no significant relationship between stock market performance and exchange rate volatility and as a result no significant impact was established. Kennedy and Nourizad (2016) applied GARCH $(1,1)$ model exchange rate volatility on US stock market from 1999 - 2010. The study took into consideration other controlling variables and established that exchange rate volatility had a positive and significant influence on stock returns. Nkoro and Uko (2016) examined the impact of exchange rate and inflation volatility on stock prices in Nigeria from 1986 to 2012 using GARCH $(1,1)$-S models as an extended GARCH-X models. The study revealed among others that stock market prices had a negative relationship with exchange rate and inflation volatility.

Worlu and Omodero (2017) did a comparative study on the effect of macroeconomic variables on stock market performances in Africa using four (4) giant African countries which include: Nigeria, Ghana, Kenya and South Africa. The study covered a period from 2000 to 2015 and the findings revealed that GDP, inflation and real exchange rate had negative impacts on Nigerian stock market performance. In the case of South Africa, GDP and inflation showed negative impacts while real exchange rate revealed no impact. For Ghana, GDP impact was negative, the other variables did not affect the stock market. In the case of Kenya, the real exchange rate had negative influence while other variables did not have effect on stock market performance. The varying findings were attributed to different economic environment the stock markets are operating as well as the rate of inflation and exchange rate variability within the periods covered. Zubair and Aladejare (2017) studied exchange rate volatility and stock market performance in Nigeria using data from 1986 - 2015 and Generalized Auto-regressive conditional heteroscedasticity technique for analysis. The study found a weak relationship between exchange rate and stock market performance proxied by stock market capitalization.

Kwofie and Ansah (2018) used Auto-Regressive Distributed Lag (ARDL) co-integration technique and the error correction parametization of the ARDL model to investigate the effect of inflation and exchange rate on stock market returns in Ghana from 2000 to 2013. The findings revealed a long run significant relationship between stock market returns and inflation while short run relationship was not established. In the same vein, the findings indicated a significant long and short run relationship between stock market returns and exchange rate returns. Mechri et al. (2019) employed GARCH model to investigate the impact of exchange rate volatility on stock market returns in two countries of the Middle East and North Africa (MENA) which are Turkey and Tunisia. The study covered a period of 15 years and found that exchange rate volatility had a significant impact on stock market returns.

\subsection{Gap in literature}

Studies on exchange rate volatility and stock market performance cannot be exhausted. The studies above were carried out in different countries and at varying periods and so the results may not be similar. However, despite the various macroeconomic factors that determine the performance of stock market internationally, this present study focuses on the impact of changes in exchange and inflation rates on stock market prices in Nigeria and covers a period from 1999 to 2018. The aim is to statistically establish an empirical evidence with a more recent data set on how these factors affect stock market prices in the country. 


\section{Methodology}

The study makes use of a descriptive research design which seeks to establish the kind of relationship existing between the predictor variables and the response variable in the selected area of research. This choice is motivated by the fact that all the variables are quantitative in nature and are numerically gathered for statistical analysis. Descriptive research design allows the researcher to statistically measure and analyze data in order to draw an empirical evidence from a study. The study is on the impact of exchange and inflation rates volatility on stock market prices. The dependent variable is the Nigerian share price index (NSPI) while the independent variables are the real exchange rate (REXG) and inflation rate (INFR). The data set on NSPI are obtained from the Central Bank of Nigeria (CBN) statistical bulletin and the Nigerian Stock Exchange while the REXG and INFR are collected from the World Bank. The data cover a period from 1999 to 2018. These data have difference values and thus were all expressed in logarithm form to achieve uniformity and for analysis. E-views version 9 is used to perform the regression analysis.

Therefore the model specification adopted for the study is stated as follows:

$\begin{array}{lll}\begin{array}{ll}\text { LOGNSPI } \\ \text { Where, }\end{array} & & \propto+\beta_{1}(\text { LOGREXG })+\beta_{2}(\text { LOGINFR })+\varepsilon \\ \text { NSPI } & = & \text { Nigerian Share Price Index } \\ \text { REXG } & = & \text { Real Exchange Rate } \\ \text { INFR } & = & \text { Inflation Rate } \\ \dot{\alpha} & = & \text { Constant } \\ \beta_{1}-\beta_{2} & = & \text { Coefficients of the regression } \\ \varepsilon & = & \text { Error term }\end{array}$

A Priori economic expectation:

$\beta_{1}, \beta_{2}>0$

The a priori economic expectation is that REXG and INFR should be greater than zero indicating positive influence on NSPI.

\section{Data analysis and interpretations}

Table 1: Regression result

Dependent Variable: LOGNSPI

Method: Least Squares

Date: 03/02/19 Time: 14:23

Sample: 19992018

Included observations: 20

\begin{tabular}{lcccr}
\hline \hline \multicolumn{1}{c}{ Variable } & Coefficient & Std. Error & t-Statistic & Prob. \\
\hline \hline LOGREXG & 2.274005 & 0.502009 & 4.529810 & 0.0003 \\
LOGINFR & 0.053254 & 0.281439 & 0.189221 & 0.8522 \\
\multicolumn{1}{c}{ C } & 0.887934 & 1.037497 & 0.855842 & 0.4040 \\
\hline \hline R-squared & 0.547075 & Mean dependent var & & 5.425646 \\
Adjusted R-squared & 0.493790 & S.D. dependent var & & 0.262952 \\
S.E. of regression & 0.187086 & Akaike info criterion & & -0.377015 \\
Sum squared resid & 0.595020 & Schwarz criterion & & -0.227655
\end{tabular}




\begin{tabular}{lllr} 
Log likelihood & 6.770146 & Hannan-Quinn criter. & -0.347858 \\
F-statistic & 10.26692 & Durbin-Watson stat & 0.602344 \\
Prob(F-statistic) & 0.001192 & & \\
\hline
\end{tabular}

Source: Author's computation 2019

Table 1 above depicts the regression result of the study which shows the existence of a very strong correlation (R) between NSPI and the predictor variables (REXG and INFR). The value of $\mathrm{R}$ is $74 \%$ (square root of $\mathrm{R}^{2}$ ), this implies a significant and robust relationship between the dependent and the independent variables. However, the value of R-squared is $54.7 \%$ which shows the extent to which REXG and INFR volatility explain the variability in the NSPI, while $45.3 \%$ is associated with other factors that are not considered in the model. The Durbin-Watson if approximately 1 which does not give cause for concern. The F-statistic is 10.26692 while the $\mathrm{p}$-value is $0.00<0.05$ level of significance. This result indicates that the model is statistically significant and appropriate for the study. In other words, the independent variables jointly influence the dependent variable significantly and positively.

The T-statistic reveals the individual performances and influences of the independent variables on the dependent variable. From table 1 above, REXG t-statistic is 4.530 while the p-value is $0.00<0.05$ level of significance. This result indicates that REXG has a significant positive impact on NSPI. There is a synchronization with this result and the findings of Kennedy and Nourizad (2016) who found that exchange rate exerted positive and significant influence on the US stock market prices. On the other hand, there is a discrepancy between this result and the findings of previous studies such as (Sekmen, 2011; Nkoro \& Uko, 2016; Worlu \& Omodero, 2017). The result fir INFR indicates insignificant positive impact which implies that inflation has not affected stock market prices within the period under review.

\section{Conclusion and recommendation}

Stock market of a nation is a major arm of the economy that helps to drive growth and development. In Nigeria, stock market is where capital is traded and obtained for businesses in the country, thus, closing assessment of its activities is very vital. This study covers a period from 1999 to 2018 using data from reliable sources to investigate the effect of two major macroeconomic factors on stock market prices. The findings reveal that inflation rate volatility within this period has not actually impacted on share prices while the exchange rate fluctuations has positive and significant impact. The REXR met the a priori expectation while the inflation rate though does not have any impact, but fell below the economic a priori expectation.

Therefore, the study recommends more stringent measures on the part of the stock market players and other relevant authorities. They should help to put in place policies that will help investors hedge against the fluctuations of the macroeconomic factors and still keep the stock market prices in the country from falling. The improvement of the stock market behavior is a very important economic decision that the government should give attention for a better economic progress. 


\section{References}

Joseph, N. (2002). Modelling the impacts of interest rate and exchange rate changes on UK stock Returns. Derivatives Use, Trading and Regulation, 7, 306-323.

Kenndy, K. \& Nourizad, F. (2016). Exchange rate volatility and its effect on stock market Volatility. International Journal of Human Capital in Urban Management, 1(1), 3746.DOI: 10.7508/IJHCUM.2016.01.005.

Kwofie, C. \& Ansah, R.K. (2018). A study of the effect of inflation and exchange rate on stock Market returns in Ghana. International Journal of Mathematics and Mathematical Sciences, Volume 2018, 1-8. DOI: 10.1155/2018/7016792.

Madura, J. (2000). International Financial Management, (8 ${ }^{\text {th }}$ Ed.).

Mburu, D.M. (2015). Relationship between exchange rate volatility and stock market Performance. M.Sc. research project submitted to the University of Nairobi.

Mechri, N., Hamad, S.B., Peretti, C. \& Charfi, S. (2019). The impact of the exchange rate Volatilities on stock markets dynamics: Evidence from Tunisia and Turkey. Hal archives. Hal id: hal-01766742v2.

Mlambo, C., Maredza, A. \& Sibanda, K. (2013). Effects of exchange rate volatility on the stock Market: A case study of South Africa. Mediterranean Journal of Social Sciences, 4(14), 561-570. DOI:10.5901/mjss.2013.v4n14p561.

Muhammad, N. \& Rasheed, A. (2011). Stock prices and exchange rates: Are they related? Evidence from South Asian Countries. Available online at: http://www.pide.org.pk/pdf/psde\%2018AGM/stock\%20prices\%20and\%20Exchange\%20r ates.pdf.

Muthike, S. W. \& Sakwa, M.M. (2012). Can macroeconomic indicators be used as predictors of The stock exchange index trends? A look at the Nairobi stock exchange. In Scientific Conference Proceedings. Available online at: http://elearning.jkuat.ac.ke/journals/ojs/index.php/jscp/article/view/731.

Nkoro, E. \& Uko, A.K. (2016). Exchange rate and inflation volatility and stock prices volatility: Evidence from Nigeria, 1986-2012. Journal of Applied Finance and Banking, 6(6), 57-70.

NSE (2018). Nigerian Stock Exchange (NSE) live. Available online at: http://www.nse.com.ng/

Sekmen, F. (2011). Exchange rate volatility and stock returns for the US. Available online at: http://www.academicjournals.org/ajbm/pdf/pdf2011/30sept/sekmen.pdf.

SSE (2019). Nigeria Stock Exchange joins United Nations Sustainable Stock Exchanges (SSE) Initiative. Available at: http://www.sseinitiative.org/.

Worlu, C.N. \& Omodero, C.O. (2017). A comparative analysis of macroeconomic variables and Stock market performances in Africa (2000-2015). International Journal of Academic Research in Accounting, Finance and Management Sciences, 7(4), 95-102. DOI: 10.6007/IJARAFMS/v7-i4/3436.

Zubair, Z.A. \& Aladejare, S.A. (2017). Exchange rate volatility and stock market performance in Nigeria. Asian Journal of Multidisciplinary studies, 5(11), 194-201. 